\title{
Henry Olerich and Utopia: \\ The Iowa Years, 1870-1902
}

H. Roger Grant*

FOR GENERATIONS THE CONCEPT OF THE PERFECT SOCIETY has fascinated Americans. Dimensions of this interest have taken a myriad of forms, running the gamut from the Puritan "Citty upon a Hill" notion in seventeenth-century New England to the drug-based philosophies of contemporary "hippie" communes in the desert Southwest. In the nineteenth century utopian activities divided largely into two types. First, there were those Americans who desired to build ideal colonies either for religious purposes or to demonstrate the practicability of some secular reform scheme; and second, there were those individuals who merely dreamed of utopia and expressed their blueprints for better societies in published novels.

During the last century Iowa was the site of two famous communitarian experiments: the sectarian Community of the True Inspiration (better known as Amana), and the secular Icarian Society. Other, but more ephemeral, utopian colonies also existed in the Hawkeye State. It appears, however, that Iowa was the home of only one nationally prominent utopian author, a man named Henry Olerich. ${ }^{1}$

\footnotetext{
*The author wishes to acknowledge the assistance of a Faculty Research Committee grant from The University of Akron for financing his research on Henry Olerich.

'For material on the American utopian novel see Allyn Forbes, "The Literary Quest for Utopia, 1880-1900," Social Forces, VI (December, 1927), 179-189; Robert L. Shurter, "The Utopian Novel in America, 1865-1900," South Atlantic Quarterly, XXXIV (April, 1935), 137-144; J. F. Normano, "Social Utopias in American Literature," International Review of Social History, III (1938), 286-300; Ellene Ransom, "Utopus Discovers America or Critical Realism in American Utopian Fiction, 1798-1900," unpublished doctoral dissertation, Vanderbilt University, 1946; Kenneth M. Roemer, "America as Utopia (1888-1900): New Vision, Old Dreams," unpublished doctoral dissertation, University of Pennsylvania, 1971; and Robert L. Shurter, The Utopian Novel in America, 1865-1900 (New York: Porcupine Press, 1972).
} 
Born on December 14, 1851 in the lead-mining village of Hazel Green, Wisconsin, Henry Olerich came from poor German immigrant stock. The Wisconsin days were full of hardship and tragedy. As Olerich remembered, "The family for a number of years during the winter . . . lived, ate and slept in one small room. None of the children attended school . . . We all wore wooden shoes and homemade clothes, and for years spoke nothing but our German dialect." Five of the twelve Olerich children died in infancy and Olerich's mother, "the real life of the family," passed away in $\mathbf{1 8 6 5}$ at the age of fortytwo. ${ }^{2}$

Initially Henry Olerich's father worked as a lead miner, but in time he acquired a small farm near Hazel Green. Then in $\mathbf{1 8 7 0}$ the family moved to Carroll County in western Iowa, where the senior Olerich purchased 640 acres of virgin prairie. Later he helped found Breda, which soon became a bustling trading center for the northwestern part of the county.

Within a year after his arrival in Iowa, Henry Olerich married a local girl, Henrietta Van Delden. He spent the early years of his married life working the Carroll County farm of his aged father-inlaw. But in 1873 he bought farm land north of Grant City in neighboring Sac County. Olerich did not remain a full-

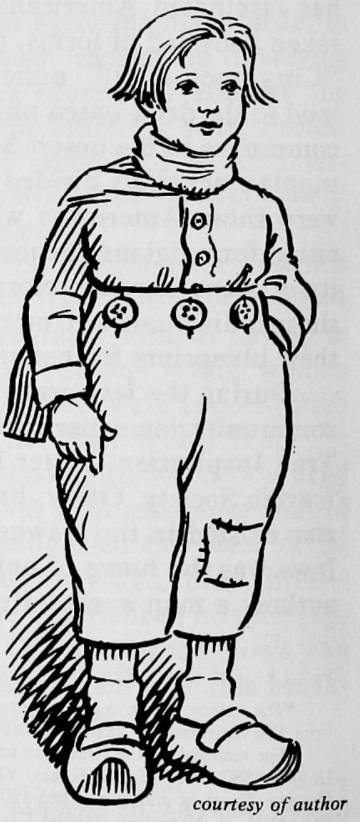

Olerich's drawing, showing his wearing apparel as a boy. 
time farmer for long. "Poverty, largely caused by a number of very wet seasons and the ravages of grasshoppers, made me a teacher ...," wrote Olerich in his autobiography. "I had practically no book-learning at that time [1875]. They [county school officials] had to take me on account of the severe scarity of teachers in that wild country.", ${ }_{3}$

Olerich's strong desire for personal advancement, coupled to his insatiable quest for knowledge, led him beyond the rural school. In his autobiography he summed up his vocational activities during the last quarter of the century:

First, my wife and I run [sic] the 'Breda Hotel' for about four years; was Station Agent and telegraph Operator [for the Chicago \& North Western Railway] at Breda for a few years; bored wells for a number of years; run [sic] father's threshing machine for one season; [and] taught school for some eighteen years, most of that time as superintendent of various city schools and teachers' Institutes.

Olerich failed to note that he served as mayor of Breda for three terms and that he passed the Iowa bar in 1894 and practiced law briefly in the Sioux County community of Hawarden. ${ }^{4}$

While school principal at Arcadia, Iowa in 1888, Olerich wrote his first book. Entitled Various Essays and published by the Herald Steam Printing House of Carroll, it expressed Olerich's amazingly diverse interests, ranging from the "Nebular Hypothesis" " theory of the universe to the question of taxing church property. In two essays, "Obedience to Law" and "Political Economy," Olerich suggested notions that he later incorporated into his utopian writings. For one, he argued that in the future "a Democratic-Republic may not always remain to be the best form of government for the most highly en-

\footnotetext{
Viola R. Storms, Moline, Illinois; hereafter cited as "Olerich Autobiography." Eighth Census of the United States, Grant County, Wisconsin, June 22, 1860.

"'Olerich Autobiography," 5-7.

'Ibid., 8-9; Letter to author from Viola R. Storms, November 20, 1973.

${ }^{s}$ Olerich did not originate the Nebular Hypothesis, rather he expanded upon various aspects of this now-dated theory of the evolution of the solar system. His most complete work on this subject, "A Modern Look at the Universe," appeared in Popular Astronomy for 1912.
} 
lightened people, as it is now." Yet, he did not indicate what might desirably replace the "Democratic-Republic." Intrigued with how to improve the over-all quality of life, Olerich speculated on a way to reduce the burden of the laboring man. "If all able-bodied inhabitants of the United States work an equal share of the aggregate that is to be done to supply these wants," he wrote, "then the average labor of each individual is at its minimum." "At this time Olerich does not seem to have been duly influenced by any one thinker. However, his reading tastes favored a variety of American "rational" and "liberal" writers, including Thomas Paine, Thomas Jefferson, Henry David Thoreau, and Robert Ingersoll.

In the closing years of the nineteeth century a severe depression gripped Iowa and the nation. Serious agricultural reversals (drought and low farm prices) beginning in the late 1880s proved disastrous to many agrarians and in 1893 urban Americans experienced their first major industrial depression. Workers by the tens of thousands suddenly joined the ranks of the unemployed and underemployed. Strikes became endemic and businesses by the thousands went bankrupt.

One response nationally to hard times was the appearance of the utopian novel. A few were published in the 1880 s, but worsening economic conditions during the nineties produced a flood of such writings. Eager to save America, the earnest authors of these works cared little about writing good literature (most lacked literary training or experience). Rather, a rich variety of reform schemes captured their total interest: some sought to show the desirability of the Henry George "single-tax" " theory of land values; others attempted to popularize producers' cooperatives; still others demanded the nationalization of industry and commerce. Often the title sug-

'Henry Olerich, Various Essays (Carroll: Herald Steam Printing Co., 1888), 23, 45.

'Henry George, a California journalist, wrote in 1879 a highly influential book, Progress and Poverty, in which he explained his "single-tax" concept. George wanted to prohibit the land speculator from reaping huge profits merely by holding onto property. A "single tax" would confiscate all this "unearned increment" of the owner. Moreover, this tax reform would bring in so much money that no other taxes would be necessary. 


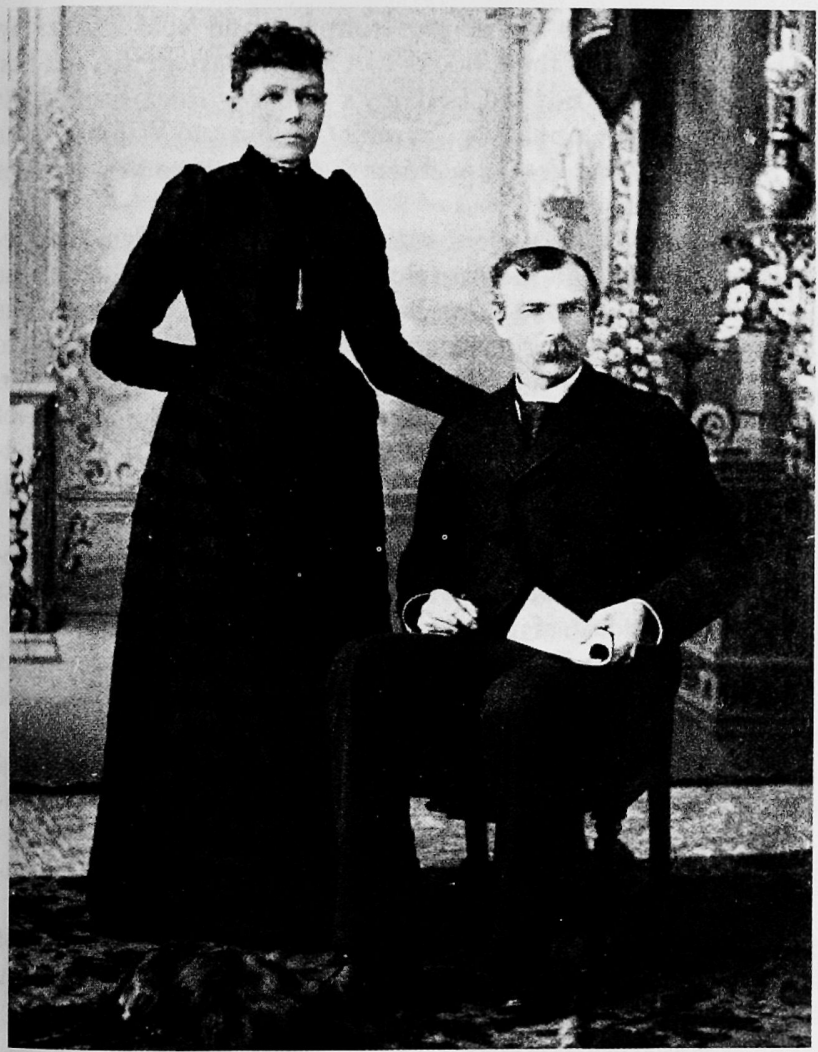

courtesy of author

Henry and Henrietta Van Delden Olerich (Photograph taken in 1878) gested the pet reform: The World a Department Store, The Co-opolitan: A Story of the Co-Operative Commonwealth of Idaho, and Nationalism. ${ }^{8}$ Typically, the utopian novel

'Bradford Peck, The World a Department Store: A Story of Life under a Cooperative System (Lewiston, Maine, 1900); Zebina Forbush, The Co-opolitan: A Story of the Co-operative Commonwealth of Idaho (Chicago: C. H. Kerr \& Co., 1898); and Crawford S. Griffin, Nationalism (Boston: C. S. Griffin, 1889). 
appeared under a vanity-press imprint and sold miserably. Only a handful of these books had any literary merit, the best examples being Edward Bellamy's Looking Backward, 20001887, Ignatius Donnelly's Caesar's Column and William Dean Howells' $A$ Traveller from Altruria. ${ }^{9}$ (And these are the ones most remembered.)

Troubled times undoubtedly caused Henry Olerich to reflect carefully upon the American condition. Disturbed by the plight of hard-pressed farmers and workers, Olerich took time from his job as superintendent of schools in Holstein, Iowa to write his best known utopian work, a novel entitled $A$ Cityless and Countryless World. ${ }^{10}$ Moreover, he formed the firm of Gilmore and Olerich in 1893 for the sole purpose of distributing the 447-page book. (It was printed in Chicago by a speciality publisher, the W. B. Conkey Company.)

Henry Olerich quickly advertised his utopian novel in reform organs and local newspapers as "The latest and most sensational book of the day" and claimed "[Edward] Bellamy's 'Looking Backward' eclipsed!" "Inlike the famous Bellamy novel, $A$ Cityless and Countryless World does not have a developed plot; it consists almost exclusively of Olerich's reform concepts. The book purports to be the tale of a perceptive resident from the planet Mars who visits a midwestern community (Holstein, Iowa?). It is through this fictional Martian, Mr. Midith, that Olerich describes his paradise in great detail.

While Henry Olerich's novel lacks a succinct statement of his utopian scheme, one passage, a speech by Midith, contains several key thoughts:

You want to bear in mind that we [residents of Mars] have a fam-

'Edward Bellamy, Looking Backward, 2000-1887 (Boston: Ticknor \& Co., 1888); Ignatius Donnelly, Caesar's Column: A Story of the Twentieth Century (Chicago: F. J. Schult \& Co., 1890); and William Dean Howells, A Traveler from Altruria: A Romance (New York: Harper \& Bros., 1894).

${ }^{10}$ Hen:y Olerich's other utopian works include: Modern Paradise, an Outline or Story of How Some of the Cultured People will Probably Live, Work and Organize in the Near Future (Omaha, 1915); The Story of the World a Thousand Years Hence (Omaha, 1923); and The New Life and Future Mating (Omaha, 1927). All were privately printed. ber, 1893 .

'See, for example, Progressive Thought and Dawn of Equality (Olathe, Kansas), Novem- 
ily; but that the family consists of a thousand or more men, women and children, instead of consisting like your family of from one to six or more. That we have no cities and towns, and no country; that our day's manual labor consists in an average of less than two hours; this you will readily see as soon as you clearly understand how vastly we economize both wealth and labor in all directions by voluntary co-operative individualism. ${ }^{12}$

For Olerich then the ideal economy is a cooperative one. He firmly believes that all members of the community should jointly own and operate the economic structure of society, "the means of production and distribution." Only through a cooperative arrangement can the monopoly or "trust" problem be forever solved.

Although the means of production and distribution are cooperatively owned, a limited form of economic individualism exists. "Labor Checks" symbolize this personal financial independence. Paper scrip is the only medium of exchange and represents the amount of work each resident performs. No one can buy what he or she has not earned. Those, however, who work at extra duties receive additional scrip and thus enjoy greater buying power. ${ }^{13}$

Since Olerich proposes a cityless and countryless-type world his utopia is devoid of both densely populated cities and isolated farmsteads. The landscape, rather, is marked off into "Communities" roughly the size of congressional townships, strongly reminiscent of the "phalanx" concept of Charles Fourier and his American disciple Albert Brisbane. ${ }^{14}$ Around the circumference of each "Community" are found the "Big Houses." Each one accommodates a "Family" of approximately a thousand residents. Every "Community" has its $54-56$

${ }^{12}$ Henry Olerich, A Cityless and Countryless World (Holstein: Gilmore \& Olerich, 1893),

${ }^{13}$ Olerich did not originate the concept of the labor check. Rather, it was the idea of a Missouri reformer G. B. De Bernardi. See H. Roger Grant, "Blueprints for Co-operative Communities: The Labor Exchange and the Colorado Cooperative Company," Journal of the West, XIII (July, 1974), 74-82.

${ }^{14}$ The phalanx, or colony, according to the Fourier-Brisbane view, would be the ideal form of social organization. Each phalanx was designed to consist of from 1,500 to 2,000 persons and was organized on a joint-stock basis with members either purchasing or earning shares and receiving dividends according to their investments. The high-water mark for this utopian concept came in the 1840 s when scores of phalanxes appeared throughout the eastern United States. 
share of factories, mines, farms, and warehouses with the distribution of surplus products taking place without profit between various communities through the agency of "Community Business Houses."

The ideal culture is directly related to the ideal economy. Communal living thrives in the "Big House." Olerich, likely remembering the harsh isolation of the Wisconsin and Iowa frontiers, encourages residents to frequent various social and cultural sections of this huge communal building, although members are assigned to individual apartments. "This arrangement," writes Olerich, "affords each person an opportunity to be with a large collection of individuals in the large parlor, or with a smaller group in various sized smaller parlors, or be all to himself in his private apartment." is

Henry Olerich continues in $A$ Cityless and Countryless World with this theory of social structure. He spends four chapters attacking the nuclear family by detailing his theories on sexual relations. A dedicated backer of women's rights and sexual freedom, Olerich has Mr. Midith describe Martians' liberated social values (p. 265):

[W] have fathers, but no husbands; mothers, but no wives. No woman gives herself away to a man for any definite length of time; and no man gives himself to any woman for a definite length of time. Consequently, we have no marriages for life, as you have. We believe that no one should have any claim on another, whether male or female, further than the mutual solicitation of the parties from time to time desire to elicit. We believe that a woman, in order to live the purest life, must be free; must enjoy the full privilege of soliciting the love of any man, or of none, if she so desires. She must be free and independent, socially, industrially and sexually.

Olerich, however, does not advocate sexual orgies. A "Victorian," he wants sexual acts only for the reproduction of the race and "he who exercises it [sex] most excessively, or who is most passionately prompted to exercise it most excessively, either in a married state, as you have it here, or under individ- 


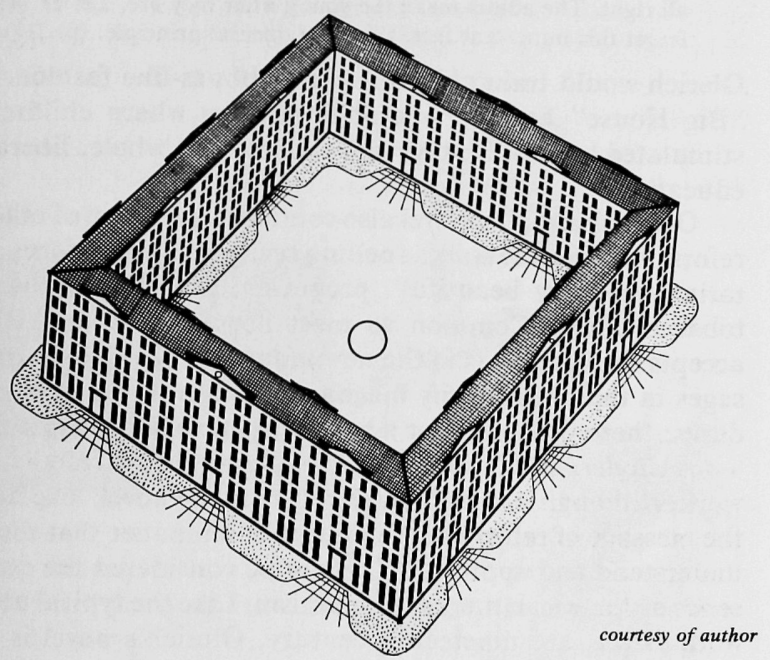

"Big House"-From Olerich's Notes

ual freedom, is the most incomplete or licentious person sexually." (p. 273)

Government in the Olerich utopia is extremely weak, unlike the structure of state in most contemporary utopian works. Organized on a simple, participatory form of democracy at the "Family" level, the utopia has "no parties, no politicians, no election frauds, no political boodle...." (p. 245) Even though Olerich later became a Socialist, he views the political process as likely to be corrupted if it is at all removed from the populace.

As an educator Henry Olerich dreams of improved pedagogical techniques. It is understandable that a substantial portion of $A$ Cityless and Countryless World focuses on educational reform. Olerich, an enthusiastic proponent of self-education, has Mr. Midith say,

Our principal aim in education is always to educate ourselves; to practice a course of conduct that we wish our children to imitate. Our children will be all right without any trouble, if we are only 
all right. The adults make the young what they are. Let us not

forget this important fact, this fundamental principle. (p. 317)

Olerich would train children in a Kibbutz-like fashion. Each "Big House" has a cooperative nursery where children are stimulated by creative toys and exposed to a whole, liberal arts education.

Olerich's utopian novel also contains a plethora of other pet reform notions. He wants spelling revision, dress reform, vegetarianism, "city beautiful" programs, prohibition and antitobacco codes. Common to most utopian authors, Olerich accepts the hard facts of the new industrial age. Extensive passages in the book glorify mechanization and scientific procedures; there is no plea for a return to subsistence agriculture.

$A$ Cityless and Countryless World is an historically valuable work. Although it is highly unlikely that the novel "explain [ed] the message of reform to the masses in a manner that they can understand and appreciate," it can be considered the quintessence of American literary utopianism. Like the typical utopian work of the late nineteenth century, Olerich's novel is not a literary masterpiece; moreover, it was written by a non-professional author and was privately printed. As with other utopian novels, $A$ Cityless and Countryless World contains a variety of reform schemes; its title is the plan; and finally, it sold poorly, in this case probably less than a thousand copies.

Henry Olerich gained considerably more fame (and fortune) for a quasi-utopian educational experiment than he did for writing $A$ Cityless and Countryless World. Instead of joining or launching one of the numerous utopian colonies of the day, Olerich and his wife adopted a baby girl so that he could demonstrate how a child should be educated. The Olerichs' son, Henry A., was twenty-five years old when they received eight-month old Viola Rosalia in the fall of 1897 . (Olerich was then superintendent of schools in Lake City, Iowa.)

"Baby Viola" quickly became a child prodigy and Henry Olerich took her on tour throughout the Middlewest between 1899 and 1902 . He rented assembly halls, opera houses or any suitable space and charged admission for a "demonstration of 


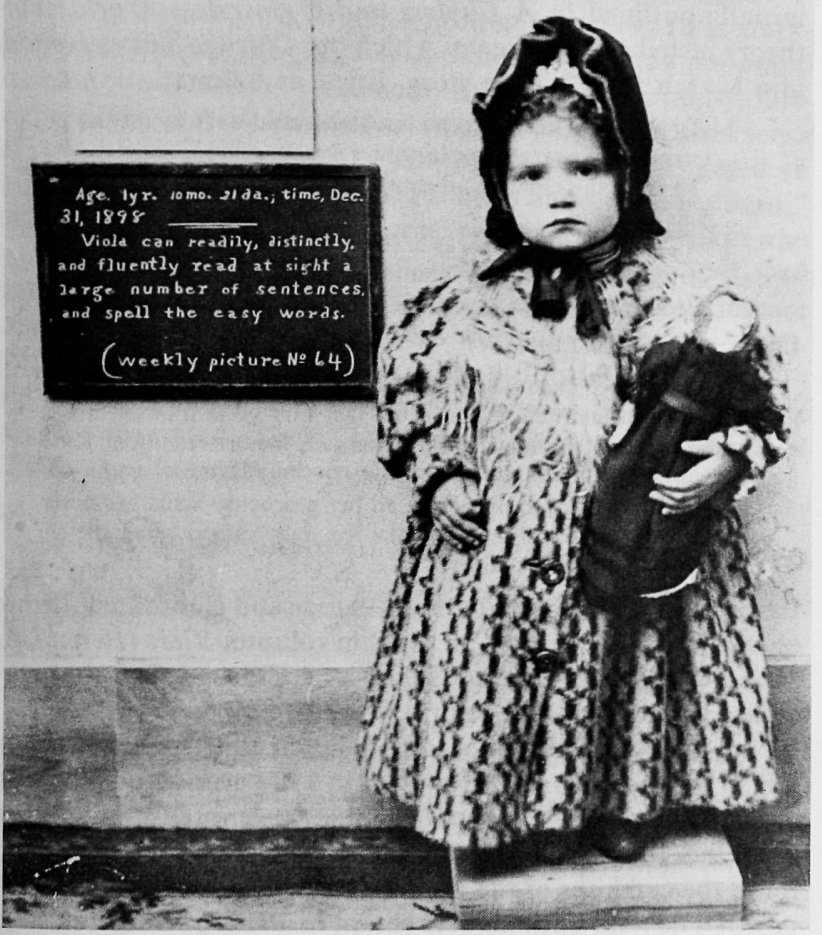

"Baby Viola"

courtesy of author

the perfectly educated child." Viola's skills were many and varied. By the age of two and one-half she could read fluently, use a typewriter, and recall an extensive variety of facts; for instance, the names and locations of the bones in the human body. She even "spelled-down" six students from Nebraska 
Wesleyan University shortly after her fourth birthday. ${ }^{16}$

Viola was more than entertainment; she symbolized Olerich's "Natural Method" philosophy of education, one that he initially outlined in A Cityless and Countryless World. This theory rested on three tenets which the Chicago Times-Herald, in a March 1899 feature story, listed as follows:

1. To awaken a keen interest for educational work by the use of attractive apparatus-playthings for the child.

2. To treat the child at all times with the greatest of kindness and equality.

3. All the educational works of the child should be an interesting game of play-purely voluntary. No elements of coercion or even undue solicitation should ever be resorted to. ${ }^{17}$

\section{Olerich told the paper:}

The secret of such wonderful success in the use of the natural method of instruction lies in the fact that great interest means undivided attention, and this attention means retention. Kind treatment and voluntary learning continually increase the delight for further inquiry. With all her precocity, Viola has never 'studied' a lesson in her life. She has only 'played,' and she always wants to play longer.

He later described his daughter's career and elaborated further on the "Natural Method" in the slim volume, Viola Olerich, the Famous Baby Scholar, published by a Chicago firm that specialized in radical and reform literature. ${ }^{18}$

In 1899 the family moved to Council Bluffs where Olerich joined the local schools. However, in 1902 over-all disgust with contemporary education philosophies prompted him to leave academe. In that year Olerich became a hand-drill press operator in the carshops of the Union Pacific Railroad in Omaha, a position he held until his retirement in 1910. Still interested in utopianism, he wrote several additional works and shortly before World War I he even proposed a communal colony to be

${ }^{16}$ Henry Olerich, "The Cleverest Child in the World," The Strand Magazine, XX (September, 1900), 130-136; Des Moines Register. September 14, 1924; H. Roger Grant, "Viola Olerich, 'The Famous Baby Scholar': An Experiment in Education," The Palimpsest, LVI (MayJune, 1975), 88-95.

${ }^{17}$ Chicago Times-Herald, March 22, 1899.

${ }^{18}$ Henry Olerich, Viola Olerich, the Famous Baby Scholar (Chicago: Larid \& Lee, 1901). 
built on the Nebraska prairie. Olerich died by suicide in Omaha on May 10, 1927 "with the copy of his latest book, 'The New Life and Future Mating,' clutched in his hand." 19

Henry Olerich, this largely forgotten Iowan, was a remarkable man. His own life graphically demonstrates how one could succeed in a frontier environment. But more importantly, Olerich represents those individuals who not only had a keen sense of justice but who fearlessly proposed what they considered an improved life for all Americans. Proud of being an "idea man," he once wrote: "I like to consider myself an original thinker who creates new concepts so that we, the progressive element, can build a better America." ${ }^{20}$ Although Olerich had little impact on social and economic change, his works provide valuable indices to earlier reform attitudes. Perhaps it is fitting in this current day of political and economic disorder that Arno Press recently reprinted Olerich's magnum opus, $A$ Cityless and Countryless World. ${ }^{21}$

${ }^{19}$ Letter to author from Viola R. Storms, November 28, 1973; Omaha World-Herald, May $11,1927$.

${ }^{20}$ Progressive Thought and Dawn of Equity, March-April, 1894.

${ }^{21}$ Arno Press, New York, 1971. 


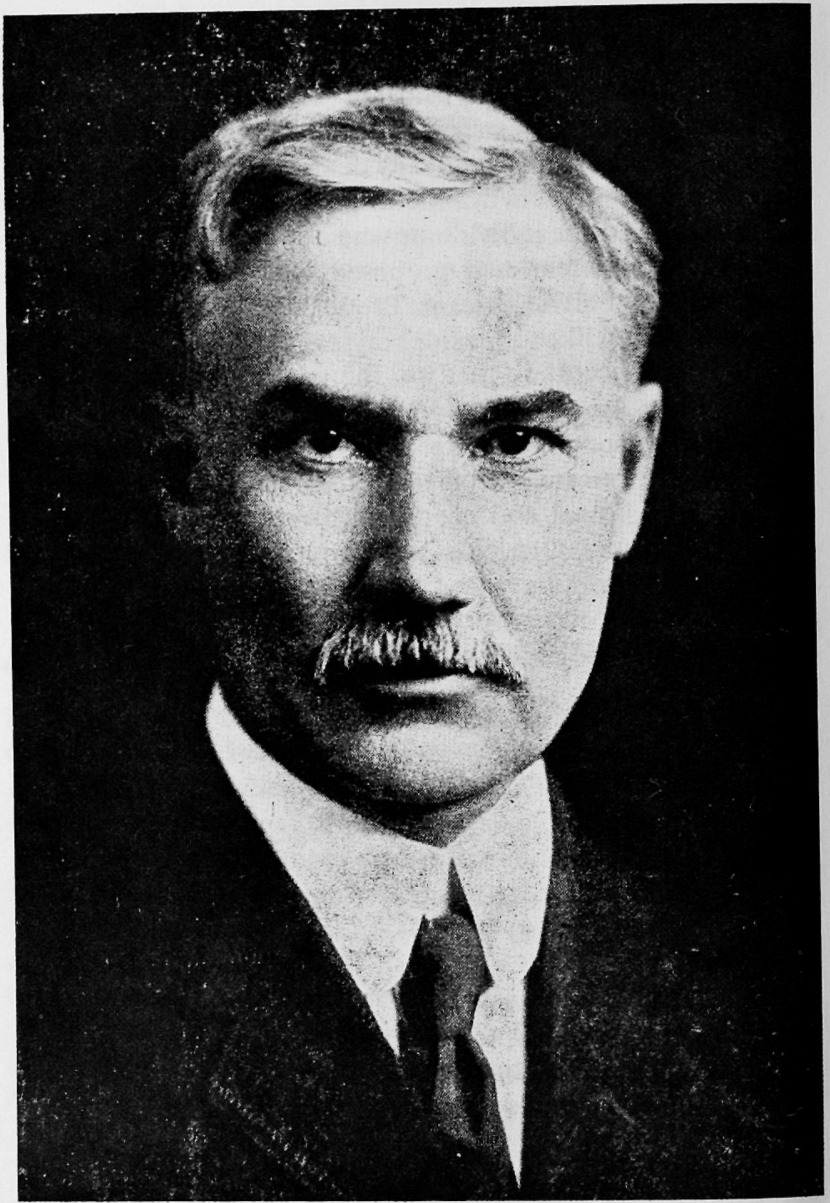

courtesy of Iowa State Historical Department, Division of Historical Museum and Archives 
Copyright of Annals of Iowa is the property of State of Iowa, by \& through the State Historical Society of Iowa and its content may not be copied or emailed to multiple sites or posted to a listserv without the copyright holder's express written permission. However, users may print, download, or email articles for individual use. 